\title{
Kecerdasan Adversity Dan Kecemasan Menghadapi Masa Pensiun
}

\author{
Nely Aldriani ${ }^{1}$, Ami Widyastuti ${ }^{2}$ \\ ${ }^{1,2}$ Fakultas Psikologi Universitas Islam Negeri Sultan Syarif Kasim Riau \\ nellyaldriani@ymail.com
}

\begin{abstract}
Abstrak
Saat memasuki masa pensiun, pegawai akan mengalami perubahan ekonomi, aktivitas, dan lingkungan sosial. Perubahan ini dapat menimbulkan kecemasan saat masa pensiun. Penelitian ini bertujuan untuk melihat pengaruh kecerdasan adversity terhadap kecemasan menghadapi masa pensiun. Hipotesis penelitian adalah terdapat pengaruh kecerdasan adversity terhadap kecemasan menghadapi masa pensiun. Sampel penelitian berjumlah 57 Pegawai Negeri Sipil (PNS) Dinas Lingkungan Hidup dan Kehutanan Provinsi Riau rentang usia 50-58 tahun yang diambil dengan menggunakan teknik pengambilan sampel purposive sampling. Alat ukur penelitian menggunakan skala kecerdasan adversity dan skala kecemasan menghadapi pensiun. Hasil analisis regresi sederhana, diperoleh hasil koefisien korelasi sebesar $r=-0,524, p<0,000$ dengan persamaan garis regresi $Y=163.658-1.048 \mathrm{X}$. Hal ini menunjukkan bahwa hipotesis diterima. Terdapat pengaruh negatif dan signifikan pada kecerdasan adversity terhadap kecemasan menghadapi masa pensiun, dengan demikian kecerdasan adversity berpengaruh pada pegawai untuk menurunkan tingkat kecemasan menghadapi masa pensiun.
\end{abstract}

Kata Kunci: Kecemasan Menghadapi Pensiun, Kecerdasan Adversity.

\begin{abstract}
Upon retirement, employees will experience changes in the economy, activities, and social environment. This change can make pre-retirement anxiety. This study aims to look at the influence of adversity quotient with pre-retirement anxiety. The hypothesis of this study is that there is an influence of adversity quotient on pre-retirement anxiety. The research samples of 57 Civil Servant of Department of Environment and Forestry of Riau with an age range of 50-58 years taken using purposive sampling technique. The research measuring instrument are adversity quotient scale and pre-retirement anxiety scale. The result of data analysis using simple regression analysis statistics, the correlation coefficient results obtained $r=-0,524, p$ $<0,000$, with a regression line equation of $Y=163.658-1.048 \mathrm{X}$. This shows that the hypothesis is accepted. There is a negative and significant influence of adversity quotient on pre-retirement anxiety. Thus, the need for adversity quotient for employees to reduce the level of pre-retirement anxiety.
\end{abstract}

Keywords: Adversity Quotient, Pre-Retirement Anxiety

\section{Pendahuluan}

Bekerja merupakan salah satu aktivitas manusia. Namun, pekerjaan yang diberikan tidak dapat dikerjakan secara terus-menerus dikarenakan adanya batasan usia 
kerja yang disebut juga dengan masa pensiun. Masa pensiun merupakan masa dimana seseorang diberhentikan dari pekerjaannya sesuai dengan batas usia pensiun yang telah ditetapkan dalam aturan pensiun (Hurlock, 2007). Berdasarkan batas usia pensiun Pegawai Negeri Sipil yang telah ditetapkan dalam Undang-Undang adalah 58 tahun, dan dapat mengajukan pensiun apabila sudah mencapai usia 50 tahun.

Pada saat memasuki masa pensiun, individu akan mengalami perubahan drastis yang akan dihadapi. Perubahan tersebut seperti perubahan pendapatan ekonomi, aktivitas sehari-hari, dan lingkungan sosial yang akan berubah. Hal ini berarti para pensiunan akan tertekan secara psikologis dan tidak lagi merasa bermanfaat dalam berkontribusi dengan lingkungan sosial (Atchley, dalam Charles, 2002). Perubahan pola kehidupan tersebut dapat menyebabkan individu menjadi cemas karena memikirkan kehidupannya ke depan.

Kecemasan dalam menghadapi masa pensiun dengan intensitas yang wajar dianggap sebagai motivasi pada diri individu, namun apabila dengan intensitas yang kuat dapat menimbulkan dampak negatif (Sutrisno, 2013). Adanya prestasi dan semangat kerja menurun; merasa frustasi dengan beban hidup, gejala fisiologis maupun psikologis yang sering muncul seperti semakin terlihat tua, tumbuhnya rambut uban, mengalami gejala kolesterol dan gula darah, dan sulit untuk mengontrol emosi; masalah ekonomi jika pegawai tidak mempersiapkan diri untuk pensiun atau tidak memiliki bekal untuk memasuki masa pensiun; masalah status sosial; dan masalah aktivitas yang akan dilakukan dimasa yang akan datang merupakan sederetan dampak negatif yang sering timbul pada waktu menjelang masa pensiun (Rahmat \& Suyanto, 2016).

Kecemasan merupakan suatu ketegangan, rasa tidak aman, dan kekhawatiran yang timbul karena dirasakan akan mengalami kejadian yang tidak menyenangkan (Maramis, 2005). Kecemasan sebagai keadaan emosional yang mempunyai ciri keterangsangan fisiologis, perasaan tegang yang tidak menyenangkan, dan keadaan khawatir yang mengeluhkan bahwa sesuatu yang buruk akan segera terjadi (Nevid, 2003). Menurut Chaplin (2002) kecemasan diartikan sebagai kekhawatiran, kegelisahan, ketakutan akan sesuatu yang akan terjadi. Hawari (2016) menyebutkan gejala-gejala kecemasan yang terjadi seperti cemas, tidak tenang, memandang masa depan dengan khawatir, kurang percaya diri, menyalahkan orang lain, serba salah, gelisah, mudah tersinggung, dramatisasi, bimbang, dan sering bertindak histeris.

Kecemasan menghadapi masa pensiun merupakan suatu perasaan tidak menyenangkan, khawatir, kebingungan, dan ketidakpastian mengenai masa depannya yang timbul ketika individu akan memasuki masa pensiun namun belum siap menerima kenyataan tersebut dengan segala akibatnya baik secara sosial, psikologis, maupun fisiologis (Hartati, 2002). Sutrisno (2013) mengungkapkan bahwa saat menghadapi masa pensiun terdapat gejala fisiologis yang sering muncul seperti mudah lelah ketika bekerja, jantung berdebar-debar, kepala pusing, serta mengalami gangguan tidur. Sedangkan gejala psikologisnya yaitu rendah diri, tidak dapat memusatkan perhatian, dan timbulnya perasaan kecewa sehingga mempengaruhi interaksi dengan lingkungan. 
Pensiun merupakan titik krisis karena terjadi akibat ketidakmampuan seseorang untuk mencari pekerjaan atau merupakan langkah akhir dalam perjalanan karir seseorang (Eliana, 2003). Corsini (dalam Eliana, 2003) mengatakan bahwa pensiun adalah proses pemisahan seorang individu dari pekerjaannya, dimana dalam menjalankan pekerjaannya seseorang digaji. Masa pensiun dianggap sebagai ancaman terhadap kehidupan seseorang di masa yang akan datang sehingga dapat menimbulkan kecemasan (Hadiwaluyo, 2009).

Nevid (2003) menjelaskan bahwa kecemasan sangat erat hubungannya dengan masa depan. Masa depan menurut Zaleski (dalam Hammad, 2016) merupakan sebuah wadah untuk merealisasikan kehidupan dan mewujudkan aspirasi, namun seorang individu tidak dapat menyakini tujuannya akan tercapai atau tidak sehingga menimbulkan kecemasan. Nevid (2003) mendefenisikan kecemasan adalah suatu keadaan emosional yang mempunyai ciri keterangsangan fisiologis, perasaan tegang yang tidak menyenangkan, dan perasaan aprehensif bahwa sesuatu yang buruk akan terjadi, yang dapat dilihat melalui ciri fisik, seperti kegelisahan, kegugupan, anggota tubuh gemetar, berkeringat, sakit pada bagian fisik, tangan yang dingin, dan mudah marah; ciri behavioral, seperti perilaku menghindar, perilaku melekat, dan perilaku terguncang; dan ciri kognitif, seperti khawatir mengenai sesuatu, keyakinan sesuatu buruk akan terjadi, berpikir bahwa dunia akan mengalami keruntuhan, berpikir akan segera mati, dan sulit berkonsentrasi.

Menurut Nevid (2003) kecemasan didasari oleh tiga aspek, yaitu: (a) Aspek Fisik, terdiri dari kegelisahan, kegugupan, anggota tubuh gemetar, banyak berkeringat, pening atau pingsan, mulut terasa kering, sulit berbicara, sulit bernafas, jantung berdebar keras, merasa lemas, anggota tubuh terasa kaku, tangan yang dingin, dan mudah marah. (b) Aspek Behavioral terdiri dari perilaku menghindar, perilaku melekat dan dependen, dan perilaku terguncang. (c) Aspek Kognitif, terdiri dari khawatir mengenai sesuatu, keyakinan bahwa sesuatu yang mengerikan akan segera terjadi, ketakutan akan kehilangan kontrol, ketakutan akan ketidakmampuan mengatasi masalah, berpikir bahwa dunia mengalami keruntuhan, berpikir akan segera mati, dan sulit berkonsentrasi.

Sejalan dengan yang dikemukakan oleh Nevid, Calhoun dan Acocella (dalam Safaria, 2009) mengemukakan aspek kecemasan dalam tiga reaksi, yaitu: (a) Reaksi Emosional, yaitu komponen kecemasan yang berkaitan dengan persepsi individu terhadap pengaruh psikologis dari kecemasan, seperti perasaan keprihatinan, ketegangan, sedih, mencela diri sendiri atau orang lain. (b) Reaksi Kognitif yaitu ketakutan dan kekhawatiran yang berpengaruh terhadap kemampuan berpikir jernih sehingga mengganggu dalam memecahkan masalah dan mengatasi tuntutan lingkungan sekitar. (c) Reaksi Fisiologis yaitu reaksi yang ditampilkan oleh tubuh terhadap sumber ketakutan dan kekhawatiran. Reaksi ini berkaitan dengan sistem syaraf yang mengendalikan berbagai otot dan kelenjar tubuh sehingga timbul reaksi dalam bentuk jantung berdetak lebih keras, nafas bergerak lebih cepat, serta tekanan darah meningkat. 
Untuk mengatasi gejala yang muncul saat menghadapi masa pensiun, pegawai diperlukan memiliki kecerdasan adversity. Menurut Stoltz (2007) kecerdasan adversity merupakan kemampuan yang dimiliki seseorang dalam mengamati kesulitan dan mengelolahnya menjadi tantangan untuk diselesaikan. Sejalan dengan penelitian Titaningsih (2010) menyebutkan bahwa salah satu determinan yang diasumsikan berperan terhadap kecemasan adalah kecerdasan adversity.

Stoltz (2007) menjelaskan bahwa kecerdasan adversity terdiri dari tiga aspek, yaitu: (a) Control atau pengedalian bertujuan untuk mengetahui seberapa banyak kendali yang dapat individu rasakan terhadap suatu peristiwa yang menimbulkan kesulitan. (b) Origin-Ownership (O2) mempertanyakan siapa atau apa yang menimbulkan kesulitan (origin) dan sejauh mana individu menganggap dirinya mempengaruhi sebagai penyebab dan asal-usul kesulitan (ownership). (c) Reach atau jangkauan mengajukan pertanyaan sejauh mana kesulitan yang dihadapi akan menjangkau bagian-bagian lain dari kehidupan individu. (d) Endurance atau daya tahan merupakan aspek yang mempertanyakan dua hal yang berkaitan yaitu berapa lama kesulitan akan berlangsung dan berapa lama penyebab kesulitan akan berlangsung.

Stoltz (2007) juga membagi manusia menjadi tiga kelompok, yaitu: (a) Quitters merupakan individu yang berhenti ditengah pendakian, mudah putus asa, mudah menyerah, cenderung pasif, tidak bergairah untuk mencapai puncak keberhasilan. Kelompok ini menolak perubahan karena kapasitasnya minimal. (b) Campers merupakan individu yang tidak mencapai puncak, sudah merasa puas dengan apa yang dicapai, individu seperti ini sedikit lebih baik dari quitters karena masih mengusahakan terpenuhnya kebutuhan rasa aman, serta masih mampu melihat tantangan. (c) Climbersmerupakan individu yang selalu berusaha mencapai puncak pendakian, berusaha menempuh kesulitan hidup dengan keberanian, selalu yakin terhadap suatu hal yang lebih besar, serta tidak pernah membiarkan hambatan untuk menghalangi pendakiannya.

Hanifa (2017) melalui penelitiannya telah membuktikan bahwa kecerdasan adversity berpengaruh terhadap kecemasan. Selain itu, penelitian yang dilakukan Rachmady dan Aprilia (2018) juga membuktikan bahwa kecerdasan adversity berhubungan dengan kecemasan dengan sumbangan efektif sebesar 35,8\%. Dalam penelitian tersebut telah dikemukakan bahwa kecerdasan adversity dapat menurunkan tingkat kecemasan pada individu. Individu dengan kecerdasan adversity yang tinggi dapat memberikan pengaruh penting terhadap kecemasan, karena kecerdasan adversity meningkatkan keyakinan individu untuk mampu mengatasi tantangan, meningkatkan keyakinan terhadap kemampuan diri pada situasi sulit, melewati batasan yang menghambat, serta mengeluarkan kemampuan yang dimiliki individu.

Kecerdasan adversity yang rendah disebabkan oleh ketidakmampuan individu dalam menghadapi kesulitan dan menemukan solusi untuk mengatasi kesulitan yang dihadapi. Akibatnya para pegawai akan cenderung mengalami kecemasan dalam menghadapi masa pensiun. Berdasarkan latar belakang yang telah dijelaskan, maka 
yang menjadi permasalahan dalam penelitian kecerdasan adversity mempengaruhi kecemasan menghadapi masa pensiun?

\section{Metode}

Penelitian ini merupakan penelitian kuantitatif. Variabel pada penelitian ini adalah Kecerdasan Adversity (variabel X) dan Kecemasan menghadapi masa pensiun (variabel Y). Jumlah sampel penelitian yaitu sebanyak 57 orang. Teknik pengambilan sampel yang digunakan adalah purposive sampling. Sampel penelitian ini memiliki kriteria yaitu, Pegawai Negeri Sipil Dinas Lingkungan Hidup dan Kehutanan Provinsi Riau yang bertugas di Kota Pekanbaru, Pegawai dengan rentang usia 50-58 tahun. Metode pengumpulan data dalam penelitian ini menggunakan skala kecerdasan adversity yang dan skala kecemasan menghadapi masa pensiun. Analisis data yang digunakan adalah regresi sederhana dengan bantuan program Statistical Product and Service Solution (SPSS) 20.0 for Windows.

\section{Hasil}

Berdasarkan data pada grafik di atas terlihat bahwa pegawai yang menjadi subjek penelitian berjumlah 57 orang dengan jumlah subjek laki-laki sebanyak 39 orang (68\%) dan subjek perempuan sebanyak 18 orang (32\%).

$$
\text { • Pegawai Laki-Laki } \quad \text { Pegawai Perempuan }
$$

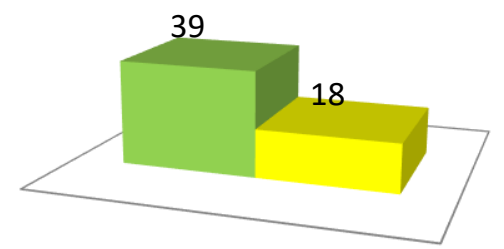

Deskripsi Subjek Berdasarkan Jenis Kelamin

Gambar 1. Demografi dan Kategorisasi

Berdasarkan data grafik di atas diketahui bahwa kategorisasi variabel kecerdasan adversity terdapat 6 orang subjek (10\%) pada kategori rendah (quitters), 42 orang subjek (74\%) pada kategori sedang (campers), dan 9 orang subjek (16\%) berada pada kategori tinggi (climber). Maka dapat disimpulkan bahwa sebagian besar pegawai memiliki kecerdasan adversity pada kategori sedang (campers) yaitu sudah merasa puas dengan keadaan sekarang.

Selanjutnya, pada kategorisasi variabel kecemasan menghadapi masa pensiun terdapat 11 orang subjek (19\%) pada kategori rendah, 34 orang subjek (60\%) pada kategori sedang, dan 12 orang subjek $(21 \%)$ berada pada kategori tinggi. Maka dapat 
disimpulkan bahwa sebagian besar pegawai memiliki kecemasan menghadapi masa pensiun yang sedang.

$\square$ Kecerdasan Adversity $\quad$ Kecemasan Menghadapi Masa Pensiun

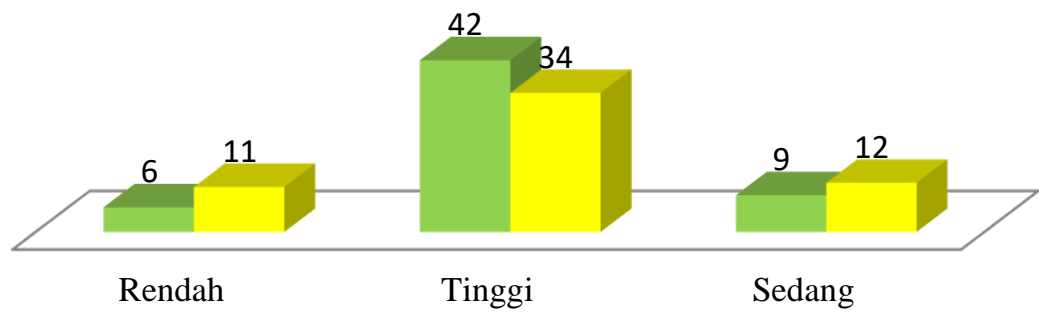

Gambar 2. kategorisasi variabel kecemasan

Hasil analisis uji hipotesis menunjukkan bahwa hipotesis diterima dengan Koefesien korelasi $r=-0,524$ dengan sumbangan efektif ( $r$ Square) $=0,275$ pada taraf signifikansi 0, 000. Selanjutnya berdasarkan tabel nilai coefficient $b$ variabel kecerdasan adversity dapat ditarik persamaan garis regresi sebagai berikut:

$$
Y=163,658-1,048 X
$$

Hasil analisis menunjukkan bahwa terdapat pengaruh negatif antara kecerdasan adversity dengan kecemasan menghadapi masa pensiun dengan nilai signifikansi 0,000 $(\mathrm{p}<0,05)$, hal ini berarti semakin tinggi kecerdasan adversity yang dimiliki pegawai maka akan semakin rendah tingkat kecemasannya dalam menghadapi masa pensiun, begitupun sebaliknya. Nilai koefisien determinasi (R square) sebesar 0,275 yang berarti bahwa kecerdasan adversity memberikan pengaruh sebesar $27,5 \%$ terhadap kecemasan mengahadapi masa pensiun.

\section{Pembahasan}

Ketika individu memasuki masa pensiun, akan dihadapkan pada kesulitankesulitan sehingga menimbulkan kecemasan. Kesulitan tersebut seperti perubahan aktivitas harian, berkurangnya pendapatan tetap, merasa kosong karena tidak ada lagi tugas yang rutin dikerjakan, perubahan peran dalam rumah tangga, muculnya fase emptiness, seperti; memutusnnya rantai sosial yang sudah terbina dengan rekan kerja, hilangnya identitas diri akan jabatan sehingga mempengaruhi harga diri dan identitas, serta hilangnya gairah hidup.

Dalam mengatasi kesulitan-kesulitan, diperlukan adanya kemampuan individu dalam kesiapan menghadapi kesulitan. Salah satu kemampuan untuk mengatasi kesulitan adalah kecerdasan adversity. Hal ini sesuai dengan penjelasan Stoltz (2007) bahwa kecerdasan adversity merupakan kemampuan individu dalam mengamati kesulitan dan mengolah kesulitan tersebut menjadi tantangan untuk diselesaikan. 
Kecerdasan adversity adalah kemampuan yang dapat digunakan untuk mengatasi kesulitan-kesulitan yang dialami individu, salah satunya adalah kecemasan.

Indikator tinggi atau rendahnya kecerdasan adversity pegawai, mengacu pada kesulitan yang akan dihadapi. Kesulitan yang dialami akan menimbulkan kecemasan, sehingga individu memberikan respon dalam menghadapi kesulitan tersebut. Nevid (2003) membagi tiga gejala kecemasan, tiga gejala tersebut terdiri dari gejala fisik, kognitif, dan perilaku. Gejala fisik meliputi pikiran yang gelisah, anggota tubuh bergetar, sakit dibeberapa bagian fisik, dan mudah marah. Gejala perilaku meliputi perilaku menghidar, perilaku melekat, dan perilaku terguncang. Gejala kognitif meliputi khawatir mengenai masa depan, sulit berkonsenterasi, dan berfikir dunia mengalami keruntuhan.

Aspek-aspek kecerdasan adversity yang terdiri dari CO2RE, akan dapat mempengaruhi gejala-gejala kecemasan dalam menghadapi masa pensiun. Pegawai yang memiliki control yang baik akan mempermudah dalam menghadapi kesulitan saat memasuki masa pensiun dikarenakan pegawai telah memiliki kendali kuat dalam mengatasi gejala-gejala kecemasan yang akan muncul. Selanjutnya, pegawai yang memiliki origin-ownership yang baik akan mempermudah dalam mengatasi kesulitan dikarenakan pegawai telah memprediksi penyebab kesulitan, sehingga pegawai akan mudah untuk menemukan solusi dari kesulitan tersebut. Kemampuan reach dalam diri pegawai akan membuat pegawai mudah dalam menjangkau kesulitan yang akan dihadapi, dengan begitu pegawai akan mempersiapkan keperluan untuk mengatasi kesulitan tersebut. Selanjutnya, endurance yang dimiliki pegawai akan mempermudah dalam mengatasi kesulitan yang menimbulkan kecemasan dikarenakan adanya kemampuan daya tahan dalam mengatasi berbagai permasalahan. Kesulitan yang dimaksud adalah hambatan-hambatan yang terjadi pada saat memasuki masa pensiun sehingga menimbulkan kecemasan. Sejalan dengan penelitian Haryandi (2019) dengan adanya control, origin-ownership, reach, serta endurance, akan dapat membantu individu dalam menghadapi kesulitan yang menyebabkan kecemasan. Pegawai yang memiliki kecerdasan adversity diprediksikan dapat mengatasi tantangan yang menjadi sumber kecemasan.

Kecerdasan adversity berguna untuk menurunkan tingkat kecemasan, tingginya kecerdasan adversity individu memberikan pengaruh penting terhadap kecemasannya (Rachmady dan Aprilia, 2018). Sehingga dapat disimpulkan bahwa kecerdasan adversity memberikan pengaruh dan berguna untuk mengatasi kecemasan yang dirasakan pada pegawai. Hal ini sejalan dengan hasil penelitian Hanifa (2017) yang mengungkapkan bahwa kecerdasan adversity berpengaruh terhadap kecemasan.

Puspitasari (dalam Rachmady dan Aprilia, 2018) juga menjelaskan bahwa individu dengan kecerdasan adversity yang tinggi akan mampu bertahan mengatasi kecemasan sehingga individu kan lebih terdorong untuk menyelesaikan kesulitan dengan baik sehingga mampu keluar dari hambatan tersebut. Hal ini membuktikan bahwasannya hasil penelitian yang dilakukan peneliti sesuai dengan hipotesis penelitian 
bahwa memang benar kecerdasan adversity berpengaruh terhadap kecemasan menghadapi masa pensiun.

Pada penelitian ini juga menemukan bahwa perbedaan jenis kelamin tidak menjadi faktor yang dapat mempengaruhi adanya kecerdasan adversity dan kecemasan menghadapi masa pensiun. Hal ini sejalan dengan penelitian yang dilakukan Cornista dan Macasaet (2013) yang mengemukakan bahwa jenis kelamin tidak berpengaruh terhadap kecerdasan adversity seseorang. Namun, penelitian yang dilakukan oleh Hasibuan (2017) menyatakan bahwa terdapat perbedaan kecemasan jika ditinjau berdasarkan jenis kelamin.

\section{Kesimpulan}

Berdasarkan hasil analisis data penelitian dapat disimpulkan bahwa kecerdasan adversity berpengaruh negatif terhadap kecemasan menghadapi masa pensiun pada pegawai Dinas Lingkungan Hidup dan Kehutanan Provinsi Riau di Kota Pekanbaru. artinya semakin tinggi kecerdasan adversity pegawai yang akan pensiun, maka kecemasan dalam menghadapi masa pensiun semakin rendah. Sebaliknya, semakin rendah kecerdasan adversity pegawai yang akan pensiun, maka kecemasannya dalam menghadapi masa pensiun semakin tinggi.

\section{Referensi}

Arini. (2018). Hubungan antara Kecerdasan Emosi dan Penerimaan Diri dengan Kecemasan Menghadapi Pensiun. Skripsi. Fakultas Psikologi Universitas Islam Sultan Syarif Kasim Pekanbaru.

Chaplin, J.P. (2002). Kamus Lengkap Psikologi. Alih Bahasa: Kartono Kartini. Jakarta: Grafindo Persada.

Charles, Kerwin, K. (2002). Is Retirement Depressing? Labor Force Inactivity and Psychological Well Being in Later Life. Journal of National Bereau of Economic Research. Massachusetts Avenue: Cambridge.

Cornista, G.A.L., \& Macasaet, C.J.A. (2013). Adversity Quotient and Achievement Motivation of Selected Third Year and Fourth Year Psychology Student of De La Salle Lipa. Thesis of Faculty of The College of Education, Arts, and Sciences. De La Salle Lipa.

Eliana, R. (2003). Konsep Diri Pensiunan. Naskah Publikasi. Program Studi Psikologi Fakultas Kedokteran Universitas Sumatera Utara.

Hadiwaluyo, D. (2009). Dampak Emosi dan Retirement. Makalah Psikogerontologi. Yogyakarta: Magister Sains Psikologi Universitas Gadjah Mada.

Hammad, M.A. (2016). Future Anxiety and its Relationship to Students' Attitude toward Academic Specialization. Journal of Education and Practice, 7(15). Universitas Najran Saudi Arabia. 
Hanifa, Y. (2017). Hubungan antara Emotional Quotient dan Adversity Quotient dengan Kecemasan Menghadapi Dunia Kerja pada Siswa SMK Muhammadiyah 1 Samarinda. Jurnal Psikoborneo, 5(1), 43-55. Program Studi Psikologi Fakultas Ilmu Sosial dan Ilmu Politik Universitas Mulawarman.

Hasibuan, N.C. (2017). Hubungan Usia, Jenis Kelamin, dan Etnis terhadap Kecemasan Komunikasi (Communication Apprehension) pada Mahasiswa di Fakultas Kedokteran Universitas Lampung. Skripsi. Fakultas Kedokteran Universitas Lampung Bandar Lampung.

Hartati, N. (2002). Post Power Syndrome Sebagai Gangguan Mental pada Masa Pensiun. Tazkiyah, 2(1).

Haryandi. (2019). Hubungan Antara Adversity Quotient dengan Kecemasan Menghadapi Tantangan Dunia Kerja pada Mahasiswa Semester Akhir. Skripsi. Fakultas Psikologi Universitas Negeri Makassar.

Hawari, D. (2016). Manajemen Stres Cemas dan Depresi. Jakarta: FKUI.

Hurlock, Elizabeth, B. (2007). Psikologi Perkembangan Suatu Pendekatan Sepanjang Rentang Kehidupan edisi Kelima. Jakarta: Erlangga.

Listari. (2018). Hubungan Antara Adversity Quotient dengan Stres Kerja pada Karyawan PT. Pelabuhan Indonesia I (PERSERO) Cabang Dumai di Kota Madya Dumai. Skripsi. Fakultas Psikologi Universitas Islam Sultan Syarif Kasim Pekanbaru.

Maramis, W.F. (2005). Catatan Ilmu Kedokteran Jiwa. Surabaya: Universitas Airlangga.

Nevid, J.S., Rathus, A.S, \& Greene, B. (2003). Psikologi Abnormal edisi Kelima jilid 1. Alih Bahasa: Tim Fakultas Psikologi Universitas Indonesia. Jakarta: Erlangga.

Rachmady, T.M.N., \& Aprilia, E.D. (2018). Hubungan Adversity Quotient dengan Kecemasan Menghadapi Dunia Kerja pada Freshgraduate Universitas Syiah Kuala. Jurnal Psikogenetik, 6(1). Program Studi Psikologi Fakultas Kedokteran Universitas Syiah Kuala.

Rahmat, A. \& Suyanto. (2016). Post-Power Syndrome dan Perubahan Perilaku Sosial Pensiunan Guru. Jurnal Ilmiah Psikologi, 3(1). Universitas Negeri Gorontalo.

Safaria, T., \& Nofrans, E.S. (2009). Manajemen Emosi. Jakarta: Bumi Aksari.

Sutrisno, E. (2013). Kematangan Emosional, Percaya Diri, dan Kecemasan Pegawai Menghadapi Masa Pensiun. Jurnal Psikologi Indonesia, 2(1), 1-11. Universitas 17 Agustus 1945 Surabaya.

Stoltz, P.G. (2007). Adversity Quotients: Mengubah Hambatan Menjadi Peluang. Alih Bahasa: T Hermaya. Jakarta: Grasindo. 
Nely, Ami

Kecerdasan Adversity Dan Kecemasan Menghadapi Masa Pensiun

Titaningsih, A. (2010). Hubungan antara Kecerdasan Adversity dengan Kecemasan Menghadapi Dunia Kerja. Skripsi. Fakultas Psikologi Universitas Muhammadiyah Surakarta. 